put forward the "ideal" appropriateness of the name for advertising purposes. In support of this, attention is drawn to the "enormous success of patent medicines possessing alliterative names." As intheir success in curing disease but in drawing money from the public attention is directed to such quack remedies as Pink Pills for Pale People, Pierce's Purgative Pellets, and Burdock's Blood Bitters; and so far as the suggestion goes that the success of such preparations depends on choice of name rather than of ingredients we can well bepany promoter should have such faith in the public, and the public in the company promoter as to bring it within the bounds of reasonable probability from a "Citv" point of view, that a company can be floated with a share capital of $£ 20,000$ for the sale of some undescribed Vaccine Virus Vanquisher, a nostrum the taking of which " renders vaccination safe by destroying any poisonous germs in the vaccine lymph as well as curing in chingtion.

ERRATUM.-In Dr. Haffkine's article on Vaccination against Cholera, published in the BRITISH MEDICAL JoURNAL of December 21st, p. 1543, in the table referring to the inoculations at Gaya Goal. under the head of the first period of five days, the third line should read 212
cinated, had 5 cases ( 236 per cent.), with 4 deaths ( 1.89 per cent.).

The Chelsea Hospital for Women.

Mr. ROBERT O'CALIAGHAN, F.R.C.S.I., writes to point out that although 123 votes were polled at Wednesday's meeting only 57 persons voted, 40 against him, and 17 for him. Neither he nor his wife voted although entitled to do so. The result in votes is brought
of cumulative voting prevailing at the hospital.

\section{The Pathogenesis of Cancer: a Correction.}

MR. W. ROGER WILliaMs, F.R.C.S. (Preston) writes: In your abstract 1 of my communication on this subject to the Manchester Medical Society there occurs a small but important misprint, which I shall feel obliged if you will rectify. I am represented by the "printer's nevil" as having said that "the process by which cancers and other The error is in the last word of this sentence, which should be "gemmation," not "generation."

Cases TReated by Biniodide of MERCURY.

DR. C. R. ILLINGWORTH. M.R.C.S. (Ritherdon Road, S.W.) writes 1. A collier was crushed by a fall of "roof," about a ton in weight. His head was pinned to the ground by one end of a large stone, making a hole beneath the left $z y$ gomatic arch an inch in depth, which bled profusely. He walked home after being rescued from his perilous position, and an hour afterwards I found him laid down, and very faint from loss of blood. The hæmorrhage had ceased, and the wound was filled level with the skin with blood clot. I stitched nothing, and simply gave a half pint bottle of 1 in 2,000 biniodide in iodide lotion Improvement began at once, and was uninterrupted. In a week the clotwas organised, and bled on being scratched. A large amount of bogun at the end of four or five days, gently, no stiffness eventually remained. Not a drop of pus and no discharge worth naming ever appeared.

2. A collier received a scalp wound down to the bone, seven inches long, and covered with coal dust. which could not be removed entirely. The wound was washed with 1 in 1,000 , and six catgut sutures were and untouched for three days. Then sutures removed, and wound found primarily united firmly throughout. One dressing only.

3. Loose cartilage in the knee-joint of a collier. Refused chioroform but accepted cociine. The patient held the cartilage himself whilst I made an incision of an inch in length into the joint. I caught the loose cartilage with a pair of catch-forceps dipped into 1 in 2,000 , and easily removed it. I then poured in about half an ounce of the same air, and lotion frothed out of the lips of theincision; sutured. Dressing on lint with 1 in 2,000 and gutta-percha tissue; back splint; next day temperature normal, and so on for five days. Got up and removed splint of own accord and then went out.

\section{Pills AND THE STOMach PUMP.}

A MEDICAL missionary who has spent the last twenty years in China, and has just returned on short furlough, tells some amusing incidents of his work, which may serve to illustrate the attitude of the Celestial mind towards Western surgery. A patient was treated one day for a charged the nominal sum for a single consultation. $A$ few days aftercharged the nominal sum for a single consultation. A few days afterwards the man returned to the hospital in restored health to complain and had been given a box of ten pills. Our friend demanded a refund of 80 and hadbeen given a box of ten pills. Our friend demanded a refund of 80 per cent. of the fee paid by him on the plea that he ought to have been charged pro rata. Quite recently another patient was brought by some friends who explained that he had been swallowing uncomfortable patient's friends roamed through the house and annexed a watch and some silver spoons Subsequently discovering his loss, the doctor sent a message to the effect that if the articles were not returned at once he would mention the facts to the Judicial Mandarin. The delinquents came and denied all knowledge of the whereabouts of the missing property, whereupon the missionary said, "There is only one place With a hasty movement, the Celestials dived into their pockets, and the lost property lay intact upon the table.

RED LIGHT TREATMENT OF CORYZA.

DR. JOHN MCMULLEN (Southport, Lancs.) writes: After reading Dr.
Niels R. Finsen's article on the Red Light Treatment of Small-pox, I

1 British Medical Journal, December 21 st. venture to mention a case of coryza which may be of interest, as it is evident the chemical rays were causing the complaint. I was called to see a young lady in June last, who was supposed to be suffering from hay fever. She had a severe attack of coryza, with a profuse discharge and especially sunlight made the discharge more profuse. I suggested the hanging of a red blind in her sitting room; this was done, with a marvellous result: she was cured in three hours. When sle left her sitting room the discharge reappeared. I prescribed red glasses, with the result that she could walk in the sunlight with impunity. The August.

WOMEN DOCTORS FOR INDIA.

L.R.C.P.\& S.ED. writes: At the present in the North-West Provinces and Oude there exists a very strong and widespread prejudice against women's quarters of an Indian household. My assertion is based on five years' experience of medical mission practice divided between two of the largest cities of North India. There are numbers of native doctors and hakims (the latter practising according to Eastern methods) who can, with some degree of truth, call themselves family doctors, but it will be enough to refer to my experience of the Indian "family practitioner" in the departments of obstetrics and gynacology alone. mystery of the male medical attendant of the zenana. I was asked on several occasions to consult with a native doctor over the case of a high caste Hindu lady. The preliminary interview always took place in the men's quarters, and only the male friends of the patient were present. An account of the subjective symptoms of the patient was given, followed by the explanation that "As custom does dhaie" (native midwife), and the diagnosis supplied by the dhaie was given, (native midwife), and the diagnosis supplied by the dhaie was ployed was utterly untrained in Western methods, yet she was supposed ployed was utterly untrained in Western methods, yet she was supposed disease. My assistance was wanted because this partnership of pracdice had not been successful in bringing the case to a satisfactory contice had not been successful in bringing the case to a satisfactory con-
clusion. After being conducted to the women's quarters, where I was instructed to make a minute examination, I had a second interview with the Doctor Babu, in which he questioned me as to the condition with the Doctor Babu, in which he questioned me as to the condition of the patient and discussed her further treatment. In only one or I never saw or heard anything more of it; he and the dhaie continued to co-operate as before, only that the treatment was modified by the new or improved diagnosis. After a good many experiences of this sort, I refused any further "catspaw" consultations. It may be urged by some that the conditions of life in the Indian zenana do not subject the inmates to the more complicated and serious
forms of disease. A glance at our statistics for the last twelve months forms of disease. A glance at our statistics for the last twelve months in the departments of obstetrics and gynæcology alone shows that out of a total of 155 native patients no fewer than 80 were submitted to
major operations. The majority of these were forceps, removal of remajor operations. The majority of these were forceps, removal of remanaged abortions. They also include 2 Porro's operations, 2 cases of placenta prævia for which turning and extraction were done, 5 craniotomies, 2 decapitations, 3 removals of large uterine fibroid polypi, 3 vesicovaginal fistulæ, and several operations for the removal of urinary calculi. I am thankful to say there is no death recorded among this number. Many of the operations were rendered necessary by the gross mismanagement of dhaies, and it is ce I tain that if no woman doctor,
trained in Western methods, had been available the majority of the trained in Western methods, had been
midwifery cases would have proved fatal.

CETTERS, COMMUNICATIONS, ETc., have been recelved from :

(A) A. B. C. (B) A. T. Brown, M.B , Horbury ; Dr. R. D. Batten, London ; Mr. F. Branwell, London; Mr. M. L. Bennett, London; Dr. G. A Bannatyne, Bath; Dr. A. J. Boyd, Ware; Dr. G. H. Broadbent, Manchester ; Dr. A. Brabazon, Bath. (C) Mr. G. B. Cresford, London; Dr. G. Carre, London; Mr. G. Crichton, London; Dr. J. G. S. Coghill Ventnor; Dr. C. J. Culling worth, London; Dr. W. H. Cooke, London Dr. T. A. Chapman, Hereford. (D) Dr. G. R. D'Aubray, Paris; Dr. W. Duncan, London; Mr. T. E. Drummond, Montreal. (․) Dr. N. Evans, Cheshunt; Mr. R. Emmett, Portsmouth; Messrs. Eyre and Spottis woode, London. (F) Dr. J. Fawcett, Tubingen; Dr. M. Foster, Cam bridge. (G) Messrs. Green and Co., London ; J. G. G. Gledhill, M.B., Hol linwood; Dr. J. Galloway, London; Mr. J. C. Galton, London. (IE) Dr S. Haynes, Malvern ; Mr. E. C. Hearne, London; Mr. G. Hartridge, Lon don; Mr. W. Habgood, London. (I) Dr. Illingworth, London. (J) Mr M. Jenkins, London; Mr. H. H. Jennings, London; Mr. J. A. Jamieson, Brodrick. (Z) Dr. T. N. Kelynack, Manchester. (I) Dr. R. W. Lowe London; L.R.C.P.and S.E.; Professor E. Ray Lankester, London. (M) M.R.C.S., L.S A.; Dr. A. Mullan, Ballymena; A. L. Marshall, M.B. London; M.R.C.S.; Dr. E. Mackenzie, Cheadle; J. McMullen, M.B. Southport; Dr. H. H. Murphy, Twickenham. (N) Dr. A. Newsholme, Brighton. (O) Mr. E. Oliver, Negopatam. (P) Provincial Medical Offlcer; Mr. M. Polson, Worcester; Mr. A. Pringle, London; Mr. N. Porritt, Huddersfield ; Mr. H. Peck, Ormskirk. (B) Mr. T. W. Richardson, Norwich ; G. Rose, M.B., Aberdeen; L. Rogers, M.B., Dorando Dr. E. S. Reynolds, Manchester. (S) Mr. C. Stephens, Banbury; Mr N. Smith, London; Mr. W. M. R. Smith, Farningham; Mr. E. D. Bhir liff, Malvern; Dr. H. Snow, London; Sir E. Saunders, London ; Dr. W A. Satchell, London; G. Sharp, M.B., Leeds. (T) Dr. Tinker, Hyde Liverpool. (W) Mr. J. H. Wigham, Leeds; Dr. H. R. Westbury, Bilbao; W. M. K.; Mr. R. M. West, Leicester; Mr. E. W. Wallis, Lon don; Dr. A. Westland, London; etc. 